\title{
Size-dependent variations on the nutritional pathway of Bathymodiolus azoricus demonstrated by a C-flux model
}

\author{
Irene Martins ${ }^{a,}{ }^{*}$, Ana Colaço ${ }^{b}$, Paul R. Dando ${ }^{c}$, Inês Martins ${ }^{b}$, Daniel Desbruyères ${ }^{d}$, Pierre- \\ Marie Sarradin ${ }^{d}$, João Carlos Marques ${ }^{a}$ and Ricardo Serrão-Santos ${ }^{b}$
}

\author{
a IMAR-Institute of Marine Research, Coimbra Interdisciplinary Centre, Department of Zoology, University of \\ Coimbra, 3004-517 Coimbra, Portugal \\ b IMAR-Institute of Marine Research, Department of Oceanography and Fisheries, University of the Azores, Cais \\ de Santa Cruz, 9901-862 Horta, Portugal \\ ${ }^{c}$ Marine Biological Association of the UK, Citadel Hill, Plymouth PL12PB, UK \\ d IFREMER, Centre de Brest, Dep. DEEP/LEP, BP70 29280 Plouzané, France
}

\author{
*: Corresponding author : I. Martins, Tel.: +351 239 836386; fax: +351 239 823603, email address : \\ imartins@ci.uc.pt
}

\begin{abstract}
:
Bathymodiolus azoricus is a mussel from vent fields in the south-west of the Azores Triple Junction (Mid-Atlantic Ridge-MAR). Experimental evidence indicates that $B$. azoricus is a mixotrophic organism, which obtains energy from a dual endosymbiosis and filter-feeding. Yet the relative contribution of symbiosis and filter-feeding to $B$. azoricus nutrition is still unclear. To address this question, we developed and individual-based model which describes sulphide and methane uptake by endosymbionts, the energy gained through microbial oxidations, the transfer of energy from endosymbionts to $B$. azoricus, filter-feeding of particulate organic matter (POC) by $B$. azoricus and the energetic wastes of the mytilid with respiration. The model accounts for size-dependent relationships obtained from empirical data. External concentrations of $\mathrm{H}_{2} \mathrm{~S}$ and $\mathrm{CH}_{4}$ correspond to estimated values for the Menez Gwen vent field, maximal and minimal values measured at MAR. From in situ observed densities of $B$. azoricus, productivity predictions at the individual level were upscale to the mytilid population at Menez Gwen and compared to estimated values. Predicted biomass of $B$. azoricus and its endosymbionts show a very high fitting level with estimated values. Results suggest that the relative contribution of filter-feeding and endosymbiosis varies with $B$. azoricus size, with small mytilids being strongly dependent on filter-feeding, whilst larger mussels obtain a significant portion of its energy from endosymbiosis. This is related with the variation of gill weight with total weight. Results also suggest that, an individual of a certain size can potentially regulate the relative contribution of filter-feeding and endosymbiosis according to external conditions. However, large $B$. azoricus exhibit a higher level of nutritional flexibility than small mytilids. The relative contribution of endosymbioisis and filter-feeding to the total energy budget of $B$. azoricus, as well as the mytilid particulate organic matter requirements, are assessed and discussed under several scenarios.
\end{abstract}

Keywords: Bathymodiolus azoricus; Endosymbiosis; Filter-feeding; Size; Organic matter; Carbon-flux model 


\section{Introduction}

Bathymodiolus azoricus is a bivalve that dominates the communities at the shallower Atlantic vent fields, south-west of the Azores Triple Junction (Mid-Atlantic Ridge): Menez Gwen (850 m) and Lucky Strike (1700 m) ([Colaço et al., 1998] and [Desbruyères et al., 2001]) (Fig. 1). Several studies revealed that B. azoricus host both thio- and methanotrophic symbionts in their gills (e.g. [Distel et al., 1995] and [Fiala-Médioni et al., 1986]) indicating that the energy obtained through microbial oxidations of the reduced compounds (sulphide and methane) released by the vents plays a significant role in the nutrition of B. azoricus ([Cavanaugh et al., 1992], [Pond et al., 1998] and [Fiala-Médioni et al., 2002]). Additionally, B. azoricus like other Bathymodiolus species also shows characteristics of a functional digestive system, such as the ciliation of the filaments which does not differ from that of littoral species, the presence of a functional feeding groove and well developed labial palps, which indicates that B. azoricus also filters and digests organic matter particles ([Le Pennec et al., 1990] and [Fiala-Médioni et al., 1986]). Uptake of dissolved organic 
matter (DOM) by B. azoricus may also occur as it has been proven in many marine invertebrates, including bivalves (Siebers and Winkler, 1984; Manahan, 1993; Wendt and Johnson, 2006). However, the factors that determine and control endosymbiosis and filter-feeding processes in $B$. azoricus, as well as the relative contribution of endosymbiosis and filter-feeding to the total energy budget of the Atlantic vent mussel are still unclear. Although, food web characterization is required as an initial step in understanding an ecosystem (Link, 2002), in vent mussel communities the complex balance of heterotrophy and autotrophy still remains to be explored (Pile and Young, 1999). One possible way to address this question is through ecological models that describe the uptake of energy from different sources and discriminate for the contribution of each source in the final energetic balance of the organism in question. Models dealing with species- or population bioenergetics are useful in clarifying the dynamics of species or populations in relation to environmental variables (Ren and Ross, 2005; Megrey et al., 2007).

The aim of this study was to understand the energetic balance of B. azoricus and its endosymbionts, with the general goal of bringing more insight into food web functioning at hydrothermal vents. Specifically, we wanted to assess the relative contribution of endosymbiosis and filter-feeding to the total energetic budget of B. azoricus under different external conditions of sulphide, methane and particulate organic matter. These questions were addressed through a carbon (C) flux model, which was upscale to the population level by incorporating quantified densities of B. azoricus at the Menez Gwen vent field.

\section{MATERIAL AND METHODS}

Model conceptualization. A carbon (C) flux model was developed to describe the energy flow through Bathymodiolus azoricus and its endosymbionts. Taking into consideration in situ observed densities (Colaço et al., 1998), the model was subsequently used to assess the 
$94 \quad \frac{\mathrm{dB}}{\mathrm{dt}}=\mathrm{T}+\mathrm{F}-\mathrm{R}$

$\frac{\mathrm{dE}}{\mathrm{dt}}=\mathrm{S}+\mathrm{M}-\mathrm{T}$

productivity of B. azoricus at the Menez Gwen vent field. Simultaneously, assuming that endosymbionts correspond to $4 \%$ of the gill wet weight of Bathymodiolus (Powell and Somero, 1986), the biomass of endosymbionts was also estimated. The model accounts for the uptake of sulphide $\left(\mathrm{H}_{2} \mathrm{~S}\right)$ and methane $\left(\mathrm{CH}_{4}\right)$, the oxidation of $\mathrm{H}_{2} \mathrm{~S}$ and $\mathrm{CH}_{4}$ by thio- and methanotrophs, respectively, the filtering of particulate organic matter (POC) by B. azoricus, the transfer of energy from the symbionts to the host and the energetic wastes of the B. azoricus (Fig. 2). The flow units of the model are mg $\mathrm{C}$ (carbon) $\mathrm{d}^{-1}$. The considered average biomass of $B$. azoricus was 500 ind $\mathrm{m}^{-2}$ according to local observations by Colaço et al. (1998). The model assumes no limiting conditions of $\mathrm{O}_{2}$ or DIC.

Mathematical equations and parameters. The biomass variation of endosymbionts $(\mathrm{E})$ and $B$. azoricus (B) is expressed by equations 1 and 2, respectively:

$\mathrm{S}$ - Energy gained from sulphide oxidation, $\mathrm{M}$ - Energy gained from methane oxidation, $\mathrm{T}-$ Transfer of energy from endosymbionts to B. azoricus, F - Energy obtained by filter-feeding, R - Energy wastes

Sulphide and methane uptake by endosymbionts. The uptake of substrates by living organisms has physiological constraints often caused by saturation when maximum thresholds are reached. In the case of bacteria, experimental evidence suggests that the uptake of substrates frequently follows a Michaelis-Menten equation, with either single, double or biphasic kinetics (e.g. Ingvorsen et al., 1984; Lovley, 1985; Unanue et al., 1999). In accordance to this, the uptake of 
104 sulphide $(\mathrm{S})$ and methane $(\mathrm{M})$ by endosymbionts $\left(\mathrm{V}_{\mathrm{S}, \mathrm{M}}\right)$ was described by a single Michaelis-

105 Menten kinetics:

106

$$
\mathrm{V}_{\mathrm{S}, \mathrm{M}}=\operatorname{Vmax}_{\mathrm{S}, \mathrm{M}} \cdot \frac{[\mathrm{S}, \mathrm{M}]}{\mathrm{Km}_{\mathrm{S}, \mathrm{M}}+[\mathrm{S}, \mathrm{M}]}
$$

$107 \operatorname{Vmax}_{\mathrm{S}, \mathrm{M}}$ - Maximum uptake rate of sulphide $(\mathrm{S})$ or methane $(\mathrm{M})\left(\mu \mathrm{mol} \mathrm{g} \mathrm{g}^{-1}\right.$ gill dry wt $\mathrm{d}^{-1}$ using a 108 gill dry wt: gill wet wt $=0.162$ based on $B$. azoricus from the Menez Gwen $(\mathrm{N}=39)), \mathrm{Km}_{\mathrm{S}, \mathrm{M}}$ -

109 Half-saturation constant for the uptake of sulphide or methane $\left(\mu \mathrm{mol} \mathrm{l}^{-1}\right),[\mathrm{S}, \mathrm{M}]-$ Concentration

110 of sulphide or methane $\left(\mu \mathrm{mol} \mathrm{l}^{-1}\right)$.

111 In the available literature, we found no values for maximum uptake rates of sulphide or methane

112 by B. azoricus, therefore, we had to use values reported for similar species. Like vent mussels, 113 methane mussels also uptake reduced substrates, mostly, through their gills (e.g. Le Pennec at 114 al., 1990) at rates ranging from $96-240 \mu \mathrm{mol} \mathrm{g}^{-1}$ wet wt d $\mathrm{d}^{-1}$ (Kochevar et al., 1992). Methane mussels only have methanotrophs in their gills, while $B$. azoricus has both thiotrophs and methanotrophs. Possibly, the uptake of methane by methane mussels is higher than the uptake of methane by B. azoricus, which can also uptake sulphide. For this reason, we assumed that the 118 average rate of methane uptake by methane mussels corresponds to the maximum methane 119 uptake rate for B. azoricus (i.e. $120 \mu \mathrm{mol} \mathrm{g}^{-1}$ wet wt gill $\mathrm{d}^{-1}$ ).

120 Model routine was used to obtain the maximum uptake of sulphide by B. azoricus (Vmax $)_{S}$ 121 while assuming that: - $\quad \operatorname{Vmax}_{\mathrm{M}}=120 \mu \mathrm{mol} \mathrm{CH} \mathrm{g}^{-1}$ wet wt gill $\mathrm{d}^{-1}$ - A certain size mussel and the corresponding biomass assuming a density of 500 ind $\mathrm{m}^{-2}$ - Endosymbiont biomass correspond $4 \%$ of the gill weight; because endosymbiont biomass depends on $\operatorname{Vmax}_{\mathrm{S}}$, the $4 \%$ value acts as a constraint that limits the variation of $\mathrm{Vmax}_{\mathrm{S}}$

126 The value that fulfilled the above pre-requisites was $743 \mu \mathrm{mol} \mathrm{H} \mathrm{S} \mathrm{g}^{-1}$ wet wt gill d $\mathrm{d}^{-1}$. 
Carbon gain from microbial oxidations. The carbon gained from chemoautotrophic microbial

129 oxidations is referred as the biomass yield for the chemotrophic growth of microorganisms

130 (expressed in C-mol : mol). According to Heijnen and Van Dijken (1992), the maximum

131 biomass yield for sulphide and methane oxidation is 0.3 and 0.55 , respectively. Due to

132 constraints of several orders, it is expected that biomass yield in the nature be significantly lower

133 than the former values. In accordance with this, empirical evidence indicates that per mole of

$134 \mathrm{CH}_{4}$ consumed, mussels with functional symbionts produce about $0.3 \mathrm{~mol} \mathrm{CO}$ (Kochevar et al.,

135 1992) and, according to the proportion 0.3:0.55 for S: CH4, the biomass yield of sulphide was

136 set at $0.16 \mathrm{~mol} \mathrm{CO}_{2}$. These processes were described by:

$137 \quad \mathrm{~S}=\mathrm{V}_{\mathrm{S}} \gamma_{\mathrm{S}}$

138 S- Carbon gain from sulphide oxidation, $V_{S}-$ Sulphide uptake, $\gamma_{S}-$ Biomass yield of sulphide

139 and

$140 \quad \mathrm{M}=\mathrm{V}_{\mathrm{M}} \gamma_{\mathrm{M}}$

141 M- Carbon gain from methane oxidation, $V_{M}-$ Methane uptake, $\gamma_{M}-$ Biomass yield of methane

143 Carbon transfer from symbionts to B. azoricus. Only part of the energy obtained from microbial

144 oxidations is transferred to the host mussel as the symbionts require some energy for their own 145 metabolism. According to Fiala-Médioni and Felbeck (1990), between 25 to 65\% of the carbon 146 fixed by the symbionts $(\delta)$ is for the host nutrition. Thus, $\mathrm{T}$ in equations 1 and 2 is defined as:

$147 \mathrm{~T}=(\mathrm{S}+\mathrm{M}) \cdot \delta$

148 The value $43 \%$ of carbon transferred from symbionts to B. azoricus was obtained through model

149 calibration (see Calibration). For the scenario (see Simulations), which accounts for the 150 digestion of symbionts by $B$. azoricus according to some experimental evidence (Fiala-Médioni 151 et al., 1986; Fisher and Childress, 1992; Raulfs et al., 2004), $\delta$ was set to $90 \%$. 
153 B. azoricus filter-feeding. Filter-feeding by mussels was described in accordance to Ren and

154 Ross (2005):

$155 \quad \mathrm{~F}=\mu . \mathrm{CR} . \mathrm{p} . \mathrm{DE}$

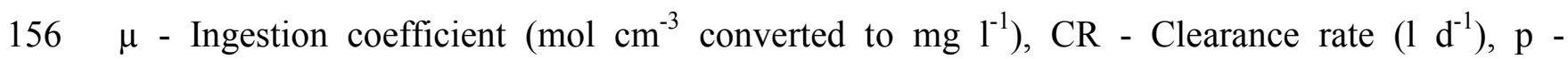

157 Functional response of particulate organic matter (POC), DE - Digestion efficiency (\%).

$158 \mathrm{p}=\frac{\mathrm{POC}}{\mathrm{POC}+\mathrm{POC}_{\mathrm{sat}}}$

159 POC - Organic matter concentration $\left(\mathrm{mg} \mathrm{l}^{-1}\right)$, POCsat - Half- saturation constant for POC (mg $1^{-}$ $\left.1600^{1}\right)$.

161 Bathymodiolus azoricus energy wastes. In the present model, the energy wastes of B. azoricus

162 were described by an allometric relation, which accounts for respiration assuming a molar ratio 163 of $\mathrm{CO}_{2}$ produced to oxygen consumed (RQ) of 0.9 :

$164 \mathrm{R}=\mathrm{aW}{ }^{\mathrm{b}} \mathrm{RQ}$

$165 \mathrm{~W}-$ Weight of B. azoricus (g dry wt), a and b - Empirical coefficients (Table 1). Coefficients a 166 and $\mathrm{b}$ are in accordance with experimental values obtained for B. azoricus (Dando et al. 167 unpublished) (Table 2). The respiration coefficient (RQ) was set at 0.9 based on the average 168 value of the reported range of 0.85 - 1 (Smith, 1985; Conway et al., 1992).

170 Biomass of $\boldsymbol{B}$. azoricus and its endosymbionts at Menez Gwen. Estimations of B. azoricus

171 biomass were based on a shell length $(\mathrm{mm})$ - dry weight $(\mathrm{g})$ regression obtained from individuals 172 of different sizes collected from Menez Gwen vent field $(\mathrm{N}=47)$ (Fig. 3A) and on an average 173 density value of $B$. azoricus observed, in situ, corresponding 550 individuals.m ${ }^{-2}$ (Colaço et al., 174 1998). To facilitate comparison with published data, B. azoricus biomass was converted to $\mathrm{kg}$

175 wet wt $\mathrm{m}^{-2}$. The relation between the gill weight (GillW-g dry wt) and total weight (TotalW-g 176 dry wt) of B. azoricus from the Menez Gwen $(\mathrm{N}=153)$ is described by the following expression 177 (Fig. 3B): 
179 Endosymbiont biomass was estimated assuming that endosymbionts correspond to $4 \%$ of the gill

180 wet weight of $B$. azoricus according with the value estimated for $B$. thermophilus (Powell and

181 Somero, 1986), using a gill wet wt:gill dry wt $=6.2$ based on B. azoricus from the Menez Gwen

$182(\mathrm{~N}=39)$ and a C: dry wt for endosymbionts of 0.5 (Bratbak 1985).

184 Calibration. The model was calibrated through the trial-error method, against the estimated

185 biomass of endosymbionts and B. azoricus at the Menez Gwen. As previously mentioned,

186 throughout the calibration process, the constraint that endosymbionts correspond to $4 \%$ of $B$. 187 azoricus gill wet weight was respected.

Sensitivity analysis. Sensitivity analysis was performed after imposing variations within the range $\pm 10 \%$ to each parameter, while all the others were kept unchanged. Sensitivity to external conditions was also tested by the series of performed simulation scenarios (see Simulations), which incorporated ranges of variations for external concentrations based on real measurements: 0.3-303 $\mu \mathrm{M} \mathrm{H}_{2} \mathrm{~S}, 0.3-177 \mu \mathrm{M} \mathrm{CH}_{4}$ and 0-0.008 $\mathrm{mg} \mathrm{l}^{-1}$ POC.

194 To estimate the sensitivity of parameters, the following expression (Jørgensen, 1994) was used:

$$
\left.S=\frac{\lfloor\partial X / X\rfloor}{[\partial P / P}\right\rfloor
$$

197 X- State variable (endosymbiont and B. azoricus biomass, in the case of the present model), PParameter, $\partial$ - Variation between the final and the initial values

200 Simulations. In every simulation, a certain initial weight of B. azoricus (in $\mathrm{mg} C$ ) and the 201 corresponding weight of endosymbionts (in $\mathrm{mg} \mathrm{C}$ ) were considered to initialize the model. At 202 each run, the model assesses if an individual mytilid, with a certain weight and harbouring the 
corresponding biomass of endosymbionts, can sustain relying on imposed external

204 concentrations. External concentrations of $\mathrm{H}_{2} \mathrm{~S}$ and $\mathrm{CH}_{4}$ used in the model are based on values estimated for the Menez Gwen or measured at MAR, while POC concentrations were estimated by model resolution, i.e., every time a certain individual B. azoricus could not sustain productivity relying on imposed $\mathrm{H}_{2} \mathrm{~S}$ and $\mathrm{CH}_{4}$ concentrations, the exact amount of POC needed to compensate for energetic wastes was estimated by trial-error method. For these purposes, a simulation length of 300 days was considered adequate.

210 In the initial simulations (scenarios 1, 2 and 3), the model was used to assess if B. azoricus and

211 its endosymbionts could sustain when relying solely on endosymbiosis or endosymbiosis 212 coupled to ingestion of symbionts. The following simulations (scenarios 4-7) were used to 213 estimate the POC requirements of B. azoricus and the relative contribution of endosymbiosis and 214 filter-feeding to B. azoricus productivity.

215 The tested scenarios were:

216 1) Only endosymbiosis with $\mathrm{H}_{2} \mathrm{~S}$ and $\mathrm{CH}_{4}$ concentrations estimated for Menez Gwen: 60 $\mu \mathrm{M}$ of $\mathrm{H}_{2} \mathrm{~S}$ and $100 \mu \mathrm{M}$ of $\mathrm{CH}_{4}$ (Sarradin, unpublished)- ENDO-MG;

2) Only endosymbiosis with $\mathrm{H}_{2} \mathrm{~S}$ and $\mathrm{CH}_{4}$ concentrations corresponding to maximal values measured at Menez Gwen, Lucky Strike and Rainbow vent fields: $303 \mu \mathrm{M}$ of $\mathrm{H}_{2} \mathrm{~S}$ and

3) Endosymbiosis and symbiont digestion with $\mathrm{H}_{2} \mathrm{~S}$ and $\mathrm{CH}_{4}$ concentrations corresponding to maximal values measured at Menez Gwen, Lucky Strike and Rainbow vent fields: ENDODIGEST-MAX;

4) Endosymbiosis and filter-feeding with external concentrations of $\mathrm{H}_{2} \mathrm{~S}$ and $\mathrm{CH}_{4}$ estimated for the Menez Gwen: ENDOFILTER-MG;

5) Endosymbiosis and filter-feeding with maximal measured concentrations of $\mathrm{H}_{2} \mathrm{~S}$ and $\mathrm{CH}_{4}$ : ENDOFILTER-MAX; 
6) Endosymbiosis and filter-feeding with $\mathrm{H}_{2} \mathrm{~S}$ and $\mathrm{CH}_{4}$ concentrations corresponding to minimal values measured at Menez Gwen, Lucky Strike and Rainbow vent fields: 0.3 $\mu \mathrm{M}$ of $\mathrm{H}_{2} \mathrm{~S}$ and $0.3 \mu \mathrm{M}$ of $\mathrm{CH}_{4}$ (Desbruyères et al., 2001): ENDOFILTER-MIN;

7) Only filter-feeding: FILTER.

A carbon to dry weight ratio of B. azoricus (C: dry wt) of 0.39 was assumed (Colaço, unpublished).

\section{RESULTS}

\section{Predicted versus estimated biomass values of $B$. azoricus and endosymbionts}

According to estimations, at the Menez Gwen vent site $B$. azoricus biomass varies between 0.01

and $9.84 \mathrm{~kg}$ wet $\mathrm{wt} \mathrm{m}^{-2}$ for mussels with sizes of 10 to $110 \mathrm{~mm} \mathrm{SL}$ (shell length), respectively, and the corresponding endosymbiont biomass variation is $13-10719 \mathrm{mg} \mathrm{C} \mathrm{m}^{-2}$ (Table 2). The fitting level between estimated and predicted values is very high for both B. azoricus and endosymbionts (ANOVA, $\mathrm{F}_{1,4}=2 \times 10^{8}, \mathrm{P}<0.001, \mathrm{r}^{2}=1$ and ANOVA, $\mathrm{F}_{1,4}=1 \times 10^{11}, \mathrm{P}<0.001, \mathrm{r}^{2}=1$, respectively) (Fig. 4A and $\mathrm{B}$ ).

\section{Contribution of endosymbiosis and filter-feeding to the nutrition of $\mathrm{B}$. azoricus}

Results indicate that, if exclusively depending on endosymbionts for nutrition and at external concentrations estimated for the Menez Gwen (ENDO-MG), B. azoricus can not keep the estimated productivity levels and show a decreasing tendency over time. This pattern is verified

248 for mussels of all sizes but the \% of decreasing productivity over time varies inversely with 249 mussel's size. At maximal concentrations measured at MAR and, either for exclusive dependency on symbiosis (ENDO-MAX) or endosymbiosis coupled to symbiont digestion (ENDODIGEST-MAX), only the largest mussels ( $\mathrm{SL}=110 \mathrm{~mm}$ ) can sustain (Fig. 5). must couple endosymbiosis with filter-feeding to reach the estimated productivity values (Fig. 
6A). However, the relative contribution of endosymbiosis and filter-feeding to the total nutrition

255 of B. azoricus varies with the size of mytilids, with the contribution of filter-feeding decreasing

256 from $81 \%$ to $16 \%$ in relation to endosymbiosis, from the smallest to the largest B. azoricus,

257 respectively (Fig. 6B).

258 The ratio filter-feeding: endosymbiosis also varies with external conditions. For maximal 259 concentrations of sulphide and methane measured at MAR (ENDOFILTER-MAX), the previous 260 pattern of nutritional strategy variation with mussel size is kept but, the contribution of filter261 feeding to the mytilid nutrition decreases, with the largest mussels being able to meet all their 262 nutritional requirements via symbiosis (Fig. 7A). If external concentrations of $\mathrm{H}_{2} \mathrm{~S}$ and $\mathrm{CH}_{4}$ 263 decrease to minimal values (ENDOFILTER-MIN), B. azoricus must increase filter-feeding rates 264 to compensate for their energetic needs. Compared to the previous scenario, the increase of 265 filter-feeding is much more significant in larger animals, which previously could rely more on 266 endosymbiosis (Fig. 7B).

267 In the scenario testing filter-feeding as the only nutritional pathway available for B. azoricus 268 (FILTER), results suggest that mytilids must filter between 0.05 and $9 \mathrm{mg}$ of POC $\mathrm{l}^{-1} \mathrm{~d}^{-1}$, 269 depending on body size (Fig. 8). According to the present results, the POC requirements of $B$. 270 azoricus also vary with body size and external conditions. For concentrations of sulphide and 271 methane estimated for the Menez Gwen, B. azoricus must filter between 0.04 to $1.4 \mathrm{mg}$ POC $1^{-1}$ $272 \mathrm{~d}^{-1}$ for the smallest and the biggest considered mussels, respectively. However, for minimal 273 concentrations or absence of reduced substrates available for microbial oxidations, the POC 274 requirements of $B$. azoricus can be as high as $9 \mathrm{mg}$ POC $\mathrm{l}^{-1} \mathrm{~d}^{-1}$ for the largest animals, 275 corresponding to a concentration of $0.008 \mathrm{mg} \mathrm{l}^{-1}$ POC (Fig. 9).

\section{Sensitivity analysis}

278 B. azoricus exhibited a higher sensitivity to parameter variations than endosymbionts (Table 3). 279 In fact, endosymbionts did not show significant sensitivity to imposed variations $( \pm 10 \%$ to the 
initial values of parameters). The parameter that caused the highest impact on the variation of 281 symbionts biomass was the amount of carbon transferred to B. azoricus ( $\delta$ ). B. azoricus showed significant sensitivity to imposed variations on respiration, ingestion efficiency, half-saturation constant for organic matter uptake and clearance rate. Interestingly, for all these parameters, the sensitivity decreases as the mytilid size increases. This indicates the stronger dependency of small mytilids on parameters related to filter-feeding compared to larger mussels. Contrarily to endosymbionts, $B$. azoricus did not react to variations on the amount of carbon transferred from the symbionts or the half-saturation constant for the uptake of $\mathrm{CH}_{4}$. B. azoricus reacted more significantly to variations on S-related parameters than to $\mathrm{CH}_{4}$-related parameters (Table 3).

\section{DISCUSSION}

\section{Biomass of $B$. azoricus and endosymbionts at the Menez Gwen}

Considering the size range $10-110 \mathrm{~mm}$ shell length, estimated biomass of $\mathrm{B}$. azoricus at the

Menez Gwen varies between 0.01 and $10 \mathrm{~kg}$ wet $\mathrm{wt} \mathrm{m}^{-2}$ (average $=3.2 \mathrm{~kg}$ wet $\mathrm{wt} \mathrm{m}^{-2}$ ), while the corresponding endosymbiont biomass ranges from 13 to $10719 \mathrm{mg} \mathrm{C} \mathrm{m}^{-2}$, which corresponds to $3.8 \mathrm{mg}$ microbial carbon $\mathrm{g}^{-1}$ wet wt gill. Our estimations of B. azoricus biomass are very similar to mussel biomasses reported for other hydrothermal vents and cold seeps (e.g. $3.5 \mathrm{~kg}$ wet wt $\mathrm{m}^{-2}$ at Lucky Strike - Van Dover et al. 1996; 2.2 kg wet wt $\mathrm{m}^{-2}$ at vents in Galápagos Ridge - Fustec et al., 1988; $5.4-9 \mathrm{~kg}$ wet wt $\mathrm{m}^{-2}$ at Barbados prism cold seeps - Olu et al., 1996). This reinforces the reliability of the present estimations, which were obtained from a significant shell 300 length-weight regression and an average density of 500 ind $\mathrm{m}^{-2}$ according to in situ observations 301 (Colaço et al., 1998).

302 Assuming a value of $10^{8}$ cell $\mu \mathrm{g} \mathrm{C}$ for the carbon content of marine bacteria, which follows within the literature range of $10^{7}-10^{10}$ cell $\mu \mathrm{g} \mathrm{C}$ (Page et al., 1990 and references therein;

304 Schippers et al., 2005), our estimations of endosymbiont biomass correspond to $3.8 \times 10^{11}$ 305 endosymbionts $\mathrm{g}^{-1}$ wet wt gill, which is in agreement with reported values of endosymbiont 
abundance for B. thermophilus (1.70-1.81 x $10^{11} \mathrm{~g}^{-1}$ wet wt- Powell and Somero, 1986) and a mytilid of the Mariana Back-arc basin $\left(0.8-2 \times 10^{11} \mathrm{~g}^{-1}\right.$ wet wt gill- Yamamoto et al., 2002). The fact that model predictions show a very high fitting level with estimated biomass values for both $B$. azoricus and its endosymbionts reflects a general correct incorporation and description of processes in the model, as well as a consistent calibration. In practical terms, this confers 311 robustness to model results and predictions for the tested scenarios.

\section{Flexibility of B. azoricus's nutritional strategy throughout life}

314 Model results suggest that the dominant nutritional strategy of $B$. azoricus varies with body size

315 and external conditions. Small and, presumably, young mytilids can not derive enough energy

316 from endosymbiosis to account for their energetic needs and, thus, filter-feeding must play an 317 important role in their nutrition. Gradually, as the mussel increases size, the amount of energy 318 derived from microbial oxidations also increases and, potentially, under non-limiting 319 concentrations of $\mathrm{H}_{2} \mathrm{~S}$ and $\mathrm{CH}_{4}$, B. azoricus is able to increase the ratio endosymbiosis: filter320 feeding. At very high availability of $\mathrm{H}_{2} \mathrm{~S}$ and $\mathrm{CH}_{4}\left(>300 \mu \mathrm{M} \mathrm{H}_{2} \mathrm{~S}\right.$ and $>150 \mu \mathrm{M} \mathrm{CH}$ ), the 321 largest and presumably older mytilids ( $\geq 110 \mathrm{~mm}$ SL) can derive all their energy from 322 endosymbiosis. However, if the concentrations of external $\mathrm{H}_{2} \mathrm{~S}$ and $\mathrm{CH}_{4}$ decrease, larger $B$. azoricus can increase the contribution of filter-feeding to meet their energetic demands, as long as the external availability of organic matter allows it. The highest nutritional flexibility of larger mussels compared to smaller ones is related with the type of allometric relationship between gill weight and the uptake of $\mathrm{H}_{2} \mathrm{~S}$ and $\mathrm{CH}_{4}$ by B. azoricus (Fig. 10). Based on 153 individuals collected in different years (2001, 2006 and 2007) and different seasons (summer, fall and winter), the average size of B. azoricus at Menez Gwen was $60 \mathrm{~mm}$ SL. According to the present model and for concentrations of $60 \mu \mathrm{M} \mathrm{H} \mathrm{H}_{2} \mathrm{~S}$ and $100 \mathrm{CH}_{4}$, mytilids of $60 \mathrm{~mm} \mathrm{SL}$ obtain about $33058 \%$ of their energy from endosymbiois and the rest from filter-feeding ( $42 \%$ ), if the available POC is $\sim 0.0067 \mathrm{mg} \mathrm{l}^{-1}$. 
The present results are also in agreement with the ontogenetic development of B. azoricus from

333 planktotrophic larvae (Dixon et al., 2006) to mixotrophic adults. In addition, the gradual

334 increasing contribution of endosymbiosis with $B$. azoricus size seems to be in accordance with

335 the possible environmental transmission of endosymbionts in the genus Bathymodiolus (Won et

336 al., 2003; Kádár et al., 2005).

\section{Spatial distribution versus nutritional strategy?}

Data from video observations and temperature time-series obtained at Menez Gwen and Lucky

340 Strike vent fields indicate that B. azoricus exhibits a spatial segregation of sizes, with largest

341 individuals living at the warmest areas with higher sulphide concentration and lower $\mathrm{pH}$ (Comtet

342 and Desbruyères, 1998 and references therein). According to our results, we hypothise that the 343 observed spatial segregation may reflect the higher dependency of larger mytilids on 344 endosymbiosis and, consequently, their location closer to the sources of reduced substrates.

345 Small mytilids, which depend more on filter-feeding are located further way from the vent flow 346 but within the mussel's bed, where particulate organic matter limitation is not likely to occur due 347 to the existence of a biogenic flow generated by mussel pumping (Pile and Young, 1999).

\section{POC requirements of $B$. azoricus}

350 In bibliography, we found a general lack of information concerning POC concentrations at vent

351 fields. The exception was some values reported for vents at the Galapagos Rift, ranging between $352106-207 \mu \mathrm{g} \mathrm{l}^{-1}$ (Smith, 1985). If values of POC at MAR are similar to these ones, according to 353 model results, B. azoricus will not experience any kind of organic carbon limitation. If the 354 predicted organic matter requirements of B. azoricus are transformed to numbers of bacteria 355 assuming that free-living bacteria are one of the components of POC at vents (Levesque et al., 356 2005) and can, thus, be filtered by mytilids (e.g. Fiala-Médioni et al., 1986; Giere et al., 2003) 357 the values range from $10^{8}-10^{9}$ bacteria $\mathrm{h}^{-1}$ (assuming $10^{8}$ cell $\mu \mathrm{g} \mathrm{C}$ ) for the tested scenarios 
accounting for endosymbiosis coupled to filter-feeding. These values are coincident with the

359 estimated amounts of bacteria required by a seep mussel: $\sim 10^{8}$ to $\sim 10^{9}$ bacteria $\mathrm{h}^{-1}$ (Page et al., 360 1990). If $B$. azoricus has to rely exclusively on filter-feeding, the number of required bacteria

361 increases to $10^{10}$ bacteria $\mathrm{h}^{-1}$ for larger mussels ( $\geq 70 \mathrm{~mm} \mathrm{SL}$ ) but, even in this situation, the 362 abundance of free-living bacteria at vents seems large enough to supply the energetic needs of $B$. azoricus $\left(\sim 10^{4}\right.$ and $\sim 10^{9}$ cells $\mathrm{ml}^{-1}$ according to Giere et al., 2003). Recent findings indicate that, although free-living primary productivity is considered to be very high at vents, the bacterial biomass may be kept at low levels due to bacterial mortality and grazing by micro- and macroinvertebrates (Levesque et al., 2005).

Dissolved organic matter (DOM) is another possible source of carbon and nutrients, if $B$. azoricus, like other marine invertebrates, is able to transport amino acids and other organic solutes across its body surface (e.g. Wendt and Johnson, 2006). In this case, vent mytilids can benefit from the potential surplus of DOM existing at mussel's beds as suggested by dissolved organic carbon (DOC) values measured in the vicinity of Bathymodiolus beds in the Lucky

372 Strike and Menez Gwen vent fields (range 95 - $647 \mu \mathrm{M}$ DOC- Sarradin et al., 1999).

Additionally, it seems that occasional peaks of surface-water primary production may act as potential food sources for both the adults and larvae of B. azoricus (Comtet et al., 2000; Dixon et al., 2006).

\section{Surviving after the cessation of vent flows}

377 The predicted plasticity of nutritional pathways exhibited by B. azoricus may explain the fact 378 that Bathymodiolus sp. is one of the last vent groups to survive after flow ceases at hydrothermal vents (Shank et al., 1998). Nevertheless, if the major source of particulate organic carbon, at vents, is provided by microbial autotrophic fixation of vent fluid DIC (Levesque et al,. 2005), the

381 ability of $B$. azoricus to survive in these circumstances will always be temporary and, most

382 likely, related to external concentrations $\left(\mathrm{H}_{2} \mathrm{~S}, \mathrm{CH}_{4}, \mathrm{POC}\right)$ at the moment flow ceases. 


\section{. Limitations of our model}

385 The model exhibits long-term stability and robustness to variations of parameters, initial- and external-conditions. Nevertheless, the model can be further improved, particularly, by incorporating experimental data, specifically, obtained for B. azoricus (e.g. clearance rate, digestion efficiency and the ratio endosymbionts: gill weight). More insight into the processes involved in the uptake of $\mathrm{S}$ and $\mathrm{CH}_{4}$ by endosymbionts will also benefit model's accuracy. For

390 instance, the dual symbiosis of B. azoricus is contemplated in the model but not linked to the environmental availability of reduced compounds, whereas experimental evidence indicates that

392 the relative number and activity of thio- and methanotrophs in B. azoricus may be related to 393 external sulphide and methane concentrations (Fiala-Médioni et al., 2002). In the future, when 394 this regulation is better understood, it can be incorporated in the model. This is valid for any 395 other process related with the use of resources and energy by B. azoricus and its endosymbionts.

\section{Conclusions}

The present results indicate that, under scenarios of external supply of sulphide, methane and POC, the predominant nutritional pathway of $B$. azoricus varies with the mytilid size, from a 400 strong dependency on filter-feeding in small mussels until deriving the majority of its energy 401 from endosymbiosis as exhibited by the largest mytilids. This variation is related with the 402 relation between gill weight and mytilid size. Depending on external conditions, the present 403 results also suggest that $B$. azoricus is able to regulate the endosymbiosis: filter-feeding-ratio, 404 with large animals showing a higher nutritional flexibility than small animals.

405 Overall this work shows that, as a complement to empirical approaches, modelling can represent 406 a valuable tool in the study and understanding of extreme ecosystems such as deep-sea 407 hydrothermal vents. 
Acknowledgements. The present work was financially supported by The Portuguese Foundation

411 for Science and Technology (FCT) through a post-doc grant to I. Martins 412 (SFRH/BPD/17654/2004), IMAR - Coimbra Interdisciplinary Centre (University of Coimbra), 413 IMAR - Department of Oceanography and Fisheries (University of the Azores) and IFREMER 414 Centre de Brest, Dep. DEEP/LEP for providing structural and experimental facilities. To V. Riou 415 for discussion of ideas.

\section{LITERATURE CITED}

Bayne BL, Hawkins AJS, Navarro E, Iglesias IP (1989) Effects of seston concentration on feeding digestion and growth in the mussel Mytilus edulis. Mar Ecol Prog Ser 55:47-54.

Bratbak G (1985) Bacterial biovolume and biomass estimations. Appl Environ Microbiol 49(6):1488-1493

Cavanaugh CM, Wirsen CO, Jannasch HW (1992) Evidence for methylotrophic bacteria in a hydrothermal-vent mussel (Bivalvia: Mytilidae) from the Mid-Atlantic Ridge. Appl Environ Microbiol 58:3799-3803

Childress JJ, Fisher CR, Brooks JM, Kennicutt MC, Bidigare R, Anderson AE (1986) A methanotrophic marine molluscan (Bivalvia, Mytilidae) symbiosis: Mussels fuelled by gas. Science 233 (4770):1306-1308

Colaço A, Desbruyères D, Comtet $T$, Alayse AM (1998) Ecology of the Menez Gwen hydrothermal vent field (Mid-Atlantic Ridge/Azores Triple Junction). Cah Biol Mar 39:237-

433 Comtet T, Desbruyères D (1998) Population structure and recruitment in mytilid bivalves from 434 the Lucky Strike and Menez Gwen hydrothermal vent fields (37 $17^{\prime} \mathrm{N}$ and $37^{\circ} 50^{\prime} \mathrm{N}$ on the Mid-Atlantic Ridge) Mar Ecol Prog Ser 163:165-177 
437 Conway NM, Howes BL, Capuzzo JEM, Turner RD, Cavanaugh CM (1992) Characterization 438 and site description of Solemya borealis (Bivalvia; Solemyidae), another bivalve-bacteria $439 \quad$ symbiosis. Mar Biol 112:601-613

440 Desbruyères D, Biscoito $\mathrm{M}$, Caprais JC, Colaço A, Comtet T, Crassous P, Fouquet Y, 441 Khripounoff A, Le Bris N, Olu K, Riso R, Sarradin PM, Segonzac M, Vangriesheim A 442 (2001) Variations in deep-sea hydrothermal vent communities on the Mid-Atlantic Ridge 443 near the Azores plateau. Deep-Sea Res Part I 48:1325-1346

444 Distel DL, Lee HKW, Cavanaugh CM (1995) Intracellular coexistence of methano- and 445 thioautotrophic bacteria in a hydrothermal vent mussel. Proc. Natl. Acad. Sci. USA 92:9598$446 \quad 9602$

447 Dixon DR, Lowe DM, Miller PI, Villemin GR, Colaço A, Serrão-Santos R, Dixon LRJ (2006) 448 Evidence of seasonal reproduction in the Atlantic vent mussel Bathymodiolus azoricus, and 449 an apparent link with the timing of photosynthetic primary production. J Mar Biol Ass UK $86: 1363-1371$

451 Fiala-Médioni A, Métivier C, Herry A, Le Pennec M (1986) Ultrastructure of the gill of the 452 hydrothermal-vent mytilid Bathymodiolus sp. Mar Biol 92:65-72

453 Fiala-Médioni A, Felbeck H (1990) Autotrophic processes in invertebrate nutrition: Bacterial 454 symbiosis in bivalve molluscs. Mellinger J (ed): Animal Nutrition and Transport Processes. 455 1. Nutrition in Wild and Domestic Animals. Comp Physiol. Basel, Karger, vol 5, pp 49-69 456 Fiala-Médioni A, McKiness ZP, Dando P, Boulegue J, Mariotti A, Alayse-Danet AM, Robinson 457 JJ, Cavanaugh CM (2002) Ultrastructural, biochemical, and immunological characterization 458 of two populations of the mytilid mussel Bathymodiolus azoricus from the Mid-Atlantic 459 Ridge: evidence for a dual symbiosis. Mar Biol 141:1035-1043 
460 Fisher CR, Childress JJ, Oremland RS, Bidigare RR (1987) The importance of methane and 461 thiosulfate in the metabolism of the bacterial symbionts of two deep-sea mussels. Mar Biol 96:59-71

463

464

465

466

467

468

469

470

471

472

473

474

475

476

477

478

479

480

481

482

483

484

485

Fustec A, Desbruyères D, Laubier L (1988) Estimation de la biomasse des peuplements associés aux sources hydrothermales profondes de la dorsale du Pacifique oriental à $13^{\circ} \mathrm{N}$. Oceanol Acta $8: 15-21$

Giere O, Borowski C, Prieur D (2003) Biological productivity in hydrothermal systems, Chapter 10. Energy and Mass Transfer in Marine Hydrothermal Systems. Edited by Halbach PE, Tunnicliffe V, Hein JR. Dahlem University Press, pp211-233

Goffredi SK, Barry P (2002) Energy acquisition and allocation in vesicomyid symbioses. Cah Biol Mar 43:345-350

Heijnen JJ, Van Dijken JP (1992) In search of a thermodynamic description of biomass yields for the chemotrophic growth of microorganisms. Biotechnol Bioeng 39:833-858

Ingvorsen K, Zehnder AJB, Jørgensen BB (1984) Kinetics of sulfate and acetate uptake by Desulfobacter postgatei. Appl Environ Microbiol 47(2):403-408

Järnegren J, Altin D (2006) Filtration and respiration of the deep sea living bivalve Acesta excavata (J.C. Fabricius, 1779) (Bivalvia; Limidae) J Exp Mar Biol Ecol 344:122-129

Jørgensen SE (1994). Fundamentals of Ecological Modelling, 2nd Edition, Elsevier, Amsterdam. Kádár E, Bettencourt R, Costa V, Serrão Santos R, Lobo-da-Cunha A, Dando P (2005) Experimentally induced endosymbiont loss and re-acquirement in the hydrothermal vent bivalve Bathymodiolus azoricus. J Exp Mar Biol Ecol 318:99-110

Kochevar RE, Childress JJ, Fisher CR, Minnich E (1992) The methane mussel: roles of symbiont and host in the metabolic utilization of methane. Mar Biol 112:389-401

Link J (2002) Does food web theory work for marine ecosystems? Mar Ecol Prog Ser 230:1-9

Le Pennec M, Donval A, Herry A (1990) Nutritional strategies of the hydrothermal ecosystem bivalves. Prog Oceanogr 24:71-80 
Levesque C, Limén H, Juniper SK (2005) Origin, composition and nutritional quality of particulate matter at deep-sea hydrothermal vents on Axial Volcano, NE Pacific. Mar Ecol Prog Ser 289:45-52

Lovley DR (1985) Minimum threshold for hydrogen metabolism in methanogenic bacteria. Appl Environ Microbiol 49(6):1530-1531

Manahan DT (1983) The uptake and metabolism of dissolved amino acids by bivalve larvae. Biol Bull 164:236-250

Megrey BA, Rose KA, Klumb RA, Hay DE, Werner FE, Eslinger DL, Smith SL (2007). A

Moloney CL, Field JG (1989) General allometric equations for rates of nutrient uptake, ingestion, and respiration in plankton organisms. Limnol Oceanogr 34(7):1290-1299

Needham HD (1996) Some features of the North America-Africa plate boundary. J Conf Abs 1:834-835

Olu K, Sibuet M, Harmegnies F, Foucher J-P, Fiala-Médioni A (1996) Spatial distribution of 502 diverse cold seep communities living on various diapiric structures of the southern Barbados prism. Prog Oceanogr 38:347-376

Page HM, Fisher CR, Childress JJ (1990) Role of filter-feeding in the nutritional biology of a deep-sea mussel with methanotrophic symbionts. Mar Biol 104: 251-257

Pile AJ, Young CM (1999) Plankton availability and retention efficiencies of cold-seep symbiont mussels. Limnol Oceanogr 44(7):1833-1839

Pond DW, Bell MV, Dixon DR, Fallick AE, Segonzac M, Sargent JR (1998) Stable-carbonisotope composition of fatty acids in hydrothermal vent mussels containing methanotrophic and thiotrophic bacterial endosymbionts. Appl Environ Microbiol 64:370-375 
511 Powell MA, Somero GN (1986) Adaptations to sulphide by hydrothermal vent animals: sites and

512 mechanisms of detoxification and metabolism. Biol Bull 171:274-290

513 Raulfs EC, Macko SA, Van Dover CL (2004) Tissue and symbiont condition of mussels

514 (Bathymodiolus thermophilus) exposed to varying levels of hydrothermal activity. J Mar Biol $515 \quad$ Ass U K 84:229-234

516 Ren JS, Ross AH (2005) Environmental influence on mussel growth: A dynamic energy budget model and its application to the greenshell mussel Perna canaliculus. Ecol. Model. $189: 347-362$

Sarradin PM, Caprais JC, Riso R, Kerouel R, Aminot A (1999) Chemical environment of the hydrothermal mussel communities in the Lucky Strike and Menez Gwen vent fields, Mid Atlantic Ridge. Cah Biol Mar 40:93-104

Schippers A, Neretin LN, Kallmeyer J, Ferdelman TG, Cragg BA, Parkes RJ, Jørgensen BB (2005) Prokaryotic cells of the deep sub-seafloor biosphere identified as living bacteria. Nature 433:861-864

Siebers D, Winkler A (1984) Amino-acid uptake by mussels, Mytilus edulis, from natural sea water in a flow-through system. Helgol Mar Res 38(1):189-199

Smith, KL (1985) Deep-sea hydrothermal vent mussels: nutritional state and distribution at the Galapagos Rift. Ecology 66(3):1067-1080

Tuttle JH (1985) The role of sulfur-oxidizing bacteria at deep-sea hydrothermal vents. Biol Soc Wash Bull 6:335-343

Unanue M, Ayo B, Agis M, Slezak D, Herndl GJ, Iriberri J (1999) Ectoenzymatic activity and uptake of monomers in marine bacterioplankton described by a biphasic kinetic model. Microb Ecol 37:36-48 
537 Wendt DE, Johnson CH (2006) Using latent effects to determine the ecological importance of 538 dissolved organic matter to marine invertebrates Int Comp Biol 46(5):634-642

539 Won Y-J, Hallam SJ, O’Mullan GD, Pan IL, Buck KR, Vrijenhoek RC (2003) Environmental 540 acquisition of thiotrophic endosymbionts by deep-sea mussels of the genus Bathymodiolus. $541 \quad$ Appl Environ Microbiol 69(11):6785-6792

542 Yamamoto H, Fujikura K, Hiraishi A, Kato K, Maki Y (2002) Phylogenetic characterization and 543 biomass estimation of endosymbionts associated with invertebrates dwelling in 544 chemosynthetic communities of hydrothermal vent and cold seep fields. Mar Ecol Prog Ser $545 \quad 245: 61-67$

546 
Figure 1- The hydrothermal vent fields south-west the Azores Triple Junction at the Mid-Atlantic Ridge (MAR).

Figure 2- Simplified conceptual diagram of the Bathymodiolus azoricus-endosymbiont C-flux model. SL- Shell length, W- Weight, $\mathrm{H}_{2} \mathrm{Sext}, \mathrm{CH}_{4}$ ext and POCext- Environmental concentrations of sulphide, methane and particulate organic matter, respectively. SulphideOxid and MethaneOxid- Sulphide and methane oxidation by endosymbionts, respectively. TransferCTransfer of carbon from endosymbionts to B. azoricus. See Table 2 and text for parameter definition.

Figure 3- Shell length (mm) versus weigh (g dry wt of soft tissue) $(\mathrm{N}=47)(\mathbf{A})$ and gill weight $(\mathrm{g}$ dry wt) versus total weight (g dry wt) $(\mathrm{N}=153)$ (B) of B. azoricus collected at Menez Gwen.

Figure 4- Predicted versus observed biomass of B. azoricus ( $\mathrm{kg}$ wet $\mathrm{wt} \mathrm{m}^{-2}$ ) (A) and endosymbionts $\left(\mathrm{mg} \mathrm{C} \mathrm{m}^{-2}\right)(\mathbf{B})$. The two regressions are highly significant: ANOVA, $\mathrm{F}_{1}$, ${ }_{4}=2 \times 10^{8}, \mathrm{P}<0.001, \mathrm{r}^{2}=1$ and ANOVA, $\mathrm{F}_{1,4}=1 \times 10^{11}, \mathrm{P}<0.001, \mathrm{r}^{2}=1$, respectively.

Figure 5- Model predictions for biomass variation of B. azoricus of different sizes (shell length$\mathrm{SL}): 10,50$ and $110 \mathrm{~mm}$ (A, B and $\mathbf{C}$, respectively), with endosymbiosis as the only carbon source and under different conditions: $\mathrm{H}_{2} \mathrm{~S}$ and $\mathrm{CH}_{4}$ concentrations estimated for Menez GwenENDO-MG (- $)$, maximal $\mathrm{H}_{2} \mathrm{~S}$ and $\mathrm{CH}_{4}$ concentrations measured at MAR- ENDO-MAX (----) and maximal concentrations with digestion of symbionts- ENDODIGEST-MAX (......).

Figure 6- Model predictions for biomass variation of B. azoricus of different sizes: $0.01 \mathrm{~kg}$ wet wt $\mathrm{m}^{-2}$ corresponding to $10 \mathrm{~mm} \mathrm{SL} \mathrm{(-),} 1.01 \mathrm{~kg}$ wet wt $\mathrm{m}^{-2}$ corresponding to $50 \mathrm{~mm}$ SL (----) 
and $9.84 \mathrm{~kg}$ wet wt $\mathrm{m}^{-2}$ corresponding to $110 \mathrm{~mm} \mathrm{SL}(. . . .$.$) with endosymbiosis and filter-$

589 feeding as carbon sources and under external concentrations of $\mathrm{H}_{2} \mathrm{~S}$ and $\mathrm{CH}_{4}$ estimated for 590 Menez Gwen (ENDOFILTER-MG) (A). The relative contribution of filter-feeding ( $\square$ ) and 591 endosymbiosis ( $\mathbf{\square})$ varies with the size of B. azoricus.

Figure 7- Relative contribution of filter-feeding ( $\square$ ) and endosymbiosis $(\%)$ to the total energy budget of $B$. azoricus of different sizes (SL- shell length) under maximal concentrations of $\mathrm{H}_{2} \mathrm{~S}$ and $\mathrm{CH}_{4}$ estimated for Menez Gwen (ENDOFILTER-MAX) (A) and minimal concentrations of $\mathrm{H}_{2} \mathrm{~S}$ and $\mathrm{CH}_{4}$ measured at MAR (ENDOFILTER-MIN) (B).

Figure 8- Organic matter needs (mg POC $\left.\mathrm{l}^{-1} \mathrm{~d}^{-1}\right)$ of $B$. azoricus of different sizes if filter-feeding 599 is the only carbon source (FILTER). Individuals with 10-, 50- and $110 \mathrm{~mm}$ SL require $0.05,0.52$ 600 and $9.1 \mathrm{mg} \mathrm{POC}^{-1} \mathrm{~d}^{-1}$, respectively, to fulfil their nutritional needs.

601

602 Figure 9- Organic matter needs (number bacteria $\mathrm{h}^{-1}$ ) of $B$. azoricus of different sizes (A- $10 \mathrm{~mm}$ S1, B- $50 \mathrm{~mm}$ SL and C- $110 \mathrm{~mm} \mathrm{SL}$ ) and under different scenarios: only with filter-feeding 604 (FILTER), with filter-feeding and endosymbiosis with external concentrations of $\mathrm{H}_{2} \mathrm{~S}_{\text {and }} \mathrm{CH}_{4}$ at 605 Menez Gwen (ENDOFILTER-MG) and maximal concentrations of $\mathrm{H}_{2} \mathrm{~S}$ and $\mathrm{CH}_{4}$ at MAR 606 (ENDOFILTER-MAX). B. azoricus with $110 \mathrm{~mm}$ SL and under ENDOFILTER-MAX scenario 607 can rely completely on endosymbiosis for nutrition.

609 Figure 10- Relationship between sulphide uptake (A) and methane uptake (B) ( $\mu \mathrm{mol} \mathrm{g}{ }^{-1}$ wet wt 610 gill $\mathrm{d}^{-1}$ ) with gill weight ( $\mathrm{g}$ wet $\mathrm{wt}$ ) in B. azoricus. 
Table 1- Parameter definition, values and mathematical expressions used in the standard run and information about literature range and methods used to obtain the final values.

Used conversion factors: wet wt $=0.1745$ dry wt (based on B. azoricus $(\mathrm{N}=35)$ from Menez Gwen). Gill dry wt: gill wet $w t=0.162$ (based on $B$. azoricus $(\mathrm{N}=35)$ from Menez Gwen), C: dry wt for B. azoricus $=0.39$ (experimentally obtained by Colaço, unpublished), C: dry wt for endosymbionts $=0.5$ (Bratbak, 1985), $\mathrm{W}=$ B. azoricus dry weight $(\mathrm{g}), \mu$ and $\mathrm{POC}_{\text {sat }}$ were subsequently converted to $\mathrm{mg} \mathrm{C}$.

\begin{tabular}{|c|c|c|c|c|c|}
\hline Parameters & Definition & $\begin{array}{c}\text { Used } \\
\text { value/expressio } \\
\text { n }\end{array}$ & Lit. range & Obs. & References \\
\hline $\begin{array}{c}\text { CR } \\
\left(1 \mathrm{~h}^{-1} \mathrm{~g}^{-1}\right)\end{array}$ & Clearance rate & $\mathrm{CR}=7.45 \mathrm{~W}^{0.66}$ & - & $\begin{array}{l}\text { Obt. for } M \text {. } \\
\quad \text { edulis }\end{array}$ & $\begin{array}{l}\text { Järnegren and } \\
\text { Altin, } 2006\end{array}$ \\
\hline $\begin{array}{c}\text { VmaxS } \\
\left(\mu \mathrm{mol} \mathrm{g}{ }^{-1} \text { wet wt gill } \mathrm{d}^{-1}\right)\end{array}$ & $\begin{array}{c}\text { Sulphide } \\
\text { maximum } \\
\text { uptake rate }\end{array}$ & 743 & $14-96$ & $\begin{array}{l}\text { Empirical+ } \\
\text { calibration }\end{array}$ & $\begin{array}{l}\text { Dando et al. } \\
\text { unpublished }\end{array}$ \\
\hline $\begin{array}{c}\mathrm{KmS} \\
\left(\mu \mathrm{mol} \mathrm{l}{ }^{-1}\right)\end{array}$ & $\begin{array}{l}\text { Sulphide half- } \\
\text { saturation } \\
\text { constant }\end{array}$ & 20 & - & Calibration & - \\
\hline $\begin{array}{c}\gamma_{\mathrm{S}} \\
(\mathrm{C}-\mathrm{mol}: \mathrm{S}-\mathrm{mol})\end{array}$ & $\begin{array}{l}\text { Carbon gained } \\
\text { from sulphide } \\
\text { oxidation }\end{array}$ & 0.16 & $0.013-0.3$ & $\begin{array}{l}\text { Empirical + } \\
\text { calibration }\end{array}$ & $\begin{array}{c}\text { Tuttle 1985; } \\
\text { Heijnen and } \\
\text { Van Dijken } \\
1992 \\
\end{array}$ \\
\hline $\begin{array}{c}\mathrm{VmaxCH}_{4} \\
\left(\mu \mathrm{mol} \mathrm{g} \mathrm{g}^{-1} \text { wet wt gill d } \mathrm{d}^{-1)}\right.\end{array}$ & $\begin{array}{l}\text { Methane } \\
\text { maximum } \\
\text { uptake rate }\end{array}$ & 120 & $96-240$ & $\begin{array}{l}\text { Empirical; obt. } \\
\text { for a cold seep } \\
\text { mussel }\end{array}$ & $\begin{array}{c}\text { Kochevar et al. } \\
1992\end{array}$ \\
\hline $\begin{array}{l}\mathrm{KmCH}_{4} \\
\left(\mu \mathrm{mol} \mathrm{l}^{-1}\right)\end{array}$ & $\begin{array}{l}\text { Methane half- } \\
\text { saturation } \\
\text { constant }\end{array}$ & 1 & - & $\begin{array}{c}\text { Empirical; obt. } \\
\text { for a cold seep } \\
\text { mussel }\end{array}$ & $\begin{array}{c}\text { Kochevar et al. } \\
1992\end{array}$ \\
\hline $\begin{array}{c}\gamma_{\mathrm{M}} \\
\left(\mathrm{C}-\mathrm{mol}: \mathrm{CH}_{4}-\mathrm{mol}\right)\end{array}$ & $\begin{array}{l}\text { Carbon gained } \\
\text { from methane } \\
\text { oxidation }\end{array}$ & 0.3 & $0.3-0.55$ & $\begin{array}{l}\text { Empirical; obt. } \\
\text { for a cold seep } \\
\text { mussel }\end{array}$ & $\begin{array}{c}\text { Heijnen and } \\
\text { Van Dijken } \\
\text { 1992; Kochevar } \\
\text { et al. } 1992\end{array}$ \\
\hline $\begin{array}{c}\delta \\
\text { (Csymb:Chost) }\end{array}$ & $\begin{array}{c}\text { Carbon } \\
\text { transferred from } \\
\text { symbionts to } \\
\text { host }\end{array}$ & 0.425 & $0.25-0.65$ & $\begin{array}{l}\text { Empirical + } \\
\text { calibration }\end{array}$ & $\begin{array}{c}\text { Fiala-Medioni } \\
\text { and Felbeck } \\
1990\end{array}$ \\
\hline$\frac{\mathrm{R}}{\left(\mu \mathrm{mol} \mathrm{C} \mathrm{g} \mathrm{g}^{-1} \text { dry wt } \mathrm{h}^{-1)}\right.}$ & $\begin{array}{c}\text { Energetic losses } \\
\text { due to } \\
\text { respiration }\end{array}$ & $\mathrm{e}^{2.69} \mathrm{~W}^{0.76}$ & & Experimental & $\begin{array}{l}\text { Dando et al. } \\
\text { unpublished }\end{array}$ \\
\hline RQ & $\begin{array}{l}\text { Respiration } \\
\text { coefficient }\end{array}$ & 0.9 & $0.85-1$ & $\begin{array}{l}\text { Experimental+ } \\
\text { calibration }\end{array}$ & $\begin{array}{c}\text { Smith 1985; } \\
\text { Conway et al. } \\
1992\end{array}$ \\
\hline $\begin{array}{c}\mu \\
\left(\mathrm{mol} \mathrm{cm}^{-3}\right)\end{array}$ & $\begin{array}{l}\text { Organic matter } \\
\text { ingestion } \\
\text { coefficient }\end{array}$ & $6.69 \times 10^{-5}$ & - & $\begin{array}{l}\text { Obtained for } P \text {. } \\
\text { canaliculus }\end{array}$ & $\begin{array}{l}\text { Ren and Ross } \\
2005 \text { and } \\
\text { references } \\
\text { therein }\end{array}$ \\
\hline $\begin{array}{l}\mathrm{DE} \\
(\%)\end{array}$ & $\begin{array}{l}\text { Organic matter } \\
\text { digestion } \\
\text { efficiency }\end{array}$ & 0.753 & $0.26-0.9$ & $\begin{array}{l}\text { Obtained for } M \text {. } \\
\quad \text { edulis }\end{array}$ & $\begin{array}{c}\text { Bayne et al. } \\
1989\end{array}$ \\
\hline $\begin{array}{l}\mathrm{POC}_{\mathrm{sat}} \\
\left(\mathrm{mol} \mathrm{l}^{-1}\right)\end{array}$ & $\begin{array}{l}\text { Half-saturation } \\
\text { constant for } \\
\text { organic matter }\end{array}$ & $1.63 \times 10^{-5}$ & - & $\begin{array}{l}\text { Obtained for } P \text {. } \\
\text { canaliculus }\end{array}$ & $\begin{array}{l}\text { Ren and Ross } \\
2005 \text { and } \\
\text { references } \\
\text { therein }\end{array}$ \\
\hline
\end{tabular}


Table 2- Estimated biomass B. azoricus and corresponding endosymbionts at the Menez Gwen, assuming an average density of 500 ind $\mathrm{m}^{-2}$ (Colaço et al., 1998) and based on a significant shell length-dry weight regression for B. azoricus $(\mathrm{N}=47)$.

\begin{tabular}{|c|c|c|c|c|c|c|}
\hline Shell length $(\mathrm{mm})$ & 10 & 30 & 50 & 70 & 90 & 110 \\
\hline $\begin{array}{l}\text { Endosymbionts } \\
\qquad\left(\mathrm{mg} \mathrm{C} \mathrm{m} \mathrm{m}^{-2}\right)\end{array}$ & 13 & 284 & 1184 & 3031 & 6118 & 10719 \\
\hline $\begin{array}{c}\text { B. azoricus } \\
\left.\text { (kg wet wt } \mathbf{~ m}^{-2}\right)\end{array}$ & 0.01 & 0.23 & 1.01 & 2.67 & 5.51 & 9.84 \\
\hline
\end{tabular}


Table 3- Sensitivity of the endosymbionts (A) and B. azoricus (B) to variations of \pm $10 \%$ in the parameters. The result is a positive or a negative number. The absolute value represents the distance to the initial value of the state variable. The negative and the positive sign indicate that the state variable and the parameters vary inversely or in the same way, respectively.

\begin{tabular}{|c|c|}
\hline A- Endosymbionts & Sensitivity \\
\hline $\mathrm{V}_{\max } \mathrm{S}+10 \%$ & 0.7 \\
\hline $\mathrm{V}_{\max } \mathrm{S}-10 \%$ & 0.7 \\
\hline $\mathrm{V}_{\max } \mathrm{CH}_{4}+10 \%$ & 0.3 \\
\hline $\mathrm{V}_{\max } \mathrm{CH}_{4}-10 \%$ & 0.3 \\
\hline$\overline{\mathrm{m}} \mathrm{S}+10 \%$ & -0.2 \\
\hline $\mathrm{K}_{\mathrm{m}} \mathrm{S}-10 \%$ & -0.2 \\
\hline $\mathrm{K}_{\mathrm{m}} \mathrm{CH}_{4}+10 \%$ & 0 \\
\hline $\mathrm{K}_{\mathrm{m}} \mathrm{CH}_{4}-10 \%$ & 0 \\
\hline$\gamma_{\mathrm{S}}+10 \%$ & 0.7 \\
\hline$\gamma_{\mathrm{S}}-10 \%$ & 0.7 \\
\hline$\gamma_{\mathrm{CH} 4}+10 \%$ & 0.3 \\
\hline$\gamma_{\mathrm{CH} 4}-10 \%$ & 0.3 \\
\hline$\delta+10 \%$ & -0.9 \\
\hline$\delta-10 \%$ & -1.1 \\
\hline
\end{tabular}




\begin{tabular}{|c|c|c|c|c|c|c|}
\hline B- В. azoricus & \multicolumn{6}{|c|}{ Sensitivity } \\
\hline SL (mm) & 10 & 30 & 50 & 70 & 90 & 110 \\
\hline $\mathrm{V}_{\max } \mathrm{S}+10 \%$ & 2.5 & 2.3 & 2.2 & 2.1 & 2.1 & 2.0 \\
\hline $\mathrm{V}_{\max } \mathrm{S}-10 \%$ & 2.5 & 2.3 & 2.2 & 2.1 & 2.1 & 2.0 \\
\hline $\mathrm{V}_{\max } \mathrm{CH}_{4}+10 \%$ & 1.1 & 1.0 & 1.0 & 0.9 & 0.9 & 0.9 \\
\hline $\mathrm{V}_{\max } \mathrm{CH}_{4}-10 \%$ & 1.1 & 1.0 & 1.0 & 0.9 & 0.9 & 0.9 \\
\hline $\mathrm{K}_{\mathrm{m}} \mathrm{S}+10 \%$ & -0.6 & -0.5 & -0.5 & -0.5 & -0.5 & -0.5 \\
\hline $\mathrm{K}_{\mathrm{m}} \mathrm{S}-10 \%$ & -0.6 & -0.5 & -0.5 & -0.5 & -0.5 & -0.5 \\
\hline $\mathrm{K}_{\mathrm{m}} \mathrm{CH}_{4}+10 \%$ & 0 & 0 & 0 & 0 & 0 & 0 \\
\hline $\mathrm{K}_{\mathrm{m}} \mathrm{CH}_{4}-10 \%$ & 0 & 0 & 0 & 0 & 0 & 0 \\
\hline$\gamma_{\mathrm{s}}+10 \%$ & 2.5 & 2.3 & 2.2 & 2.1 & 2.1 & 2.0 \\
\hline$\gamma_{\mathrm{S}}-10 \%$ & 2.5 & 2.3 & 2.2 & 2.1 & 2.1 & 2.0 \\
\hline$\gamma_{\mathrm{CH} 4}+10 \%$ & 1.1 & 1.0 & 1.0 & 0.9 & 0.9 & 0.9 \\
\hline$\gamma_{\mathrm{CH} 4}-10 \%$ & 1.1 & 1.0 & 1.0 & 0.9 & 0.9 & 0.9 \\
\hline$\delta+10 \%$ & 0 & 0 & 0 & 0 & 0 & 0 \\
\hline$\delta-10 \%$ & 0 & 0 & 0 & 0 & 0 & 0 \\
\hline $\mathrm{CR}+10 \%$ & 12 & 4.6 & 3.2 & 2.2 & 1.7 & 1.0 \\
\hline CR $-10 \%$ & 8.6 & 6.5 & 3.5 & 2.1 & 1.1 & 0.7 \\
\hline $\mathrm{R}+10 \%$ & -8.7 & -7.5 & -6.2 & -5.2 & -4.4 & -3.8 \\
\hline R-10\% & -18.5 & -8.6 & -6.6 & -5.1 & -4.4 & -3.8 \\
\hline $\mathrm{POC}_{\mathrm{sat}}+10 \%$ & -8.2 & -5.4 & -3.0 & -1.9 & -1.2 & -0.8 \\
\hline $\mathrm{POC}_{\text {sat }}-10 \%$ & -17.8 & -6.6 & -3.7 & -2.3 & -1.5 & -0.9 \\
\hline$\mu+10 \%$ & 16.3 & 6.0 & 3.4 & 2.1 & 1.4 & 0.9 \\
\hline$\mu-10 \%$ & 8.4 & 5.8 & 3.4 & 2.1 & 1.4 & 0.8 \\
\hline
\end{tabular}


Figure 1

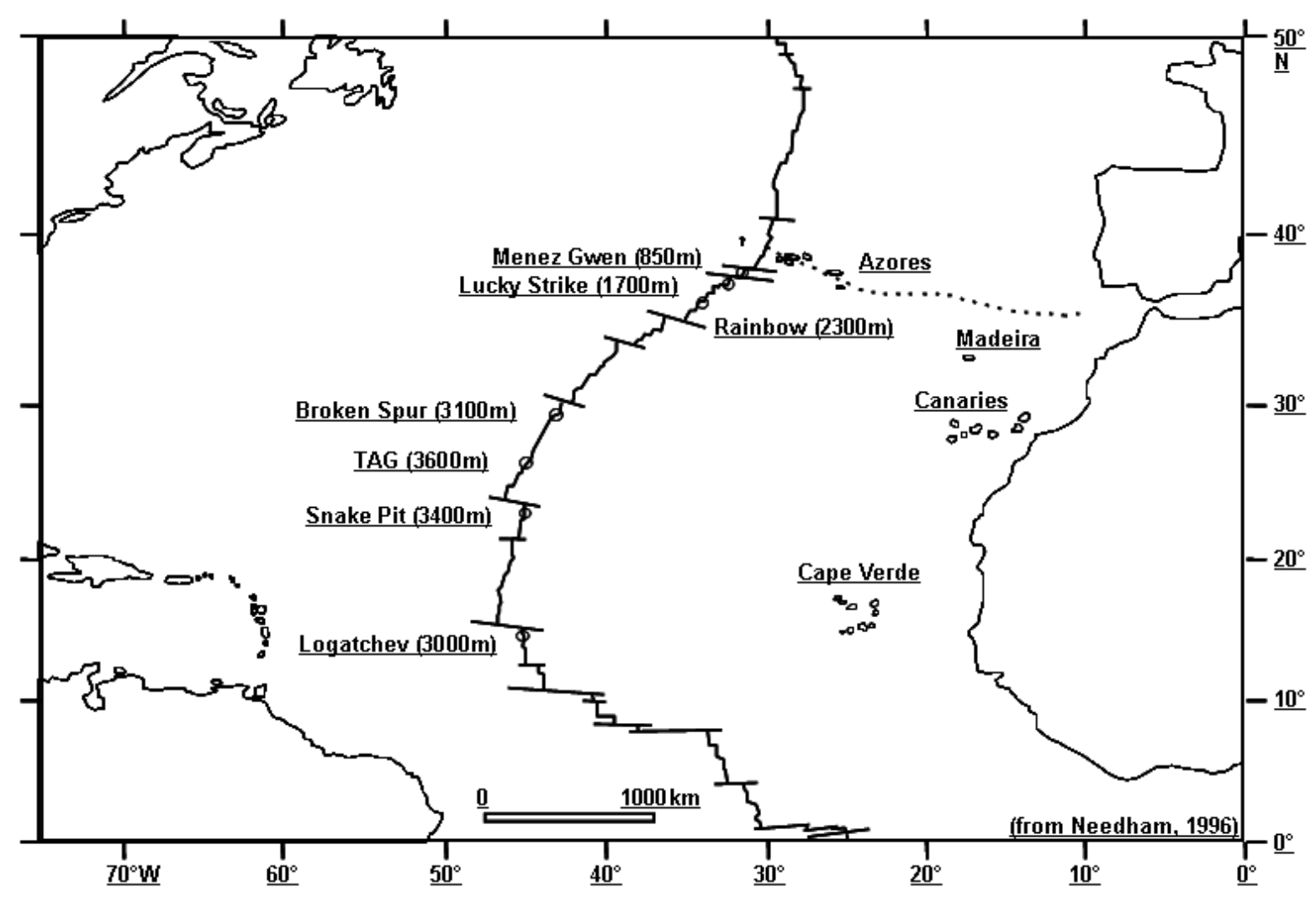




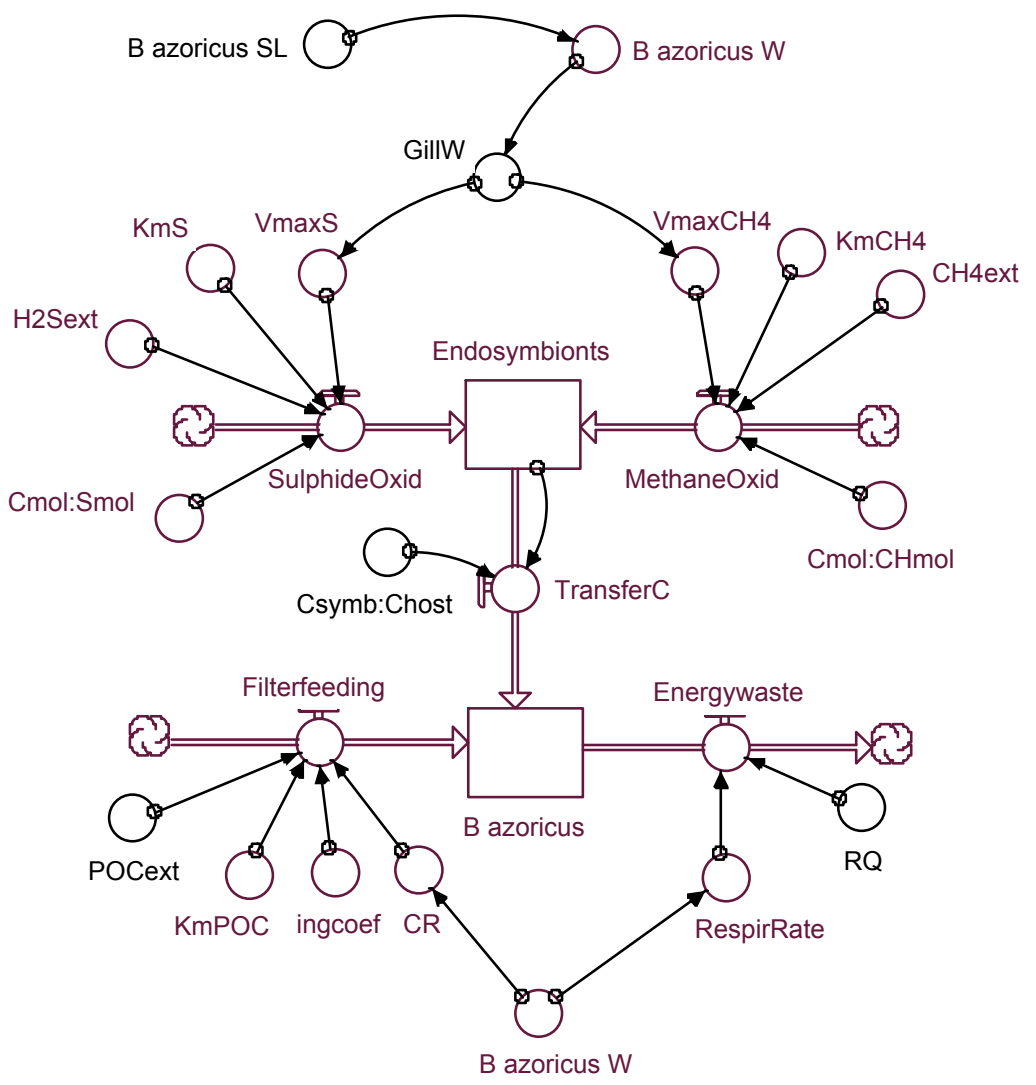



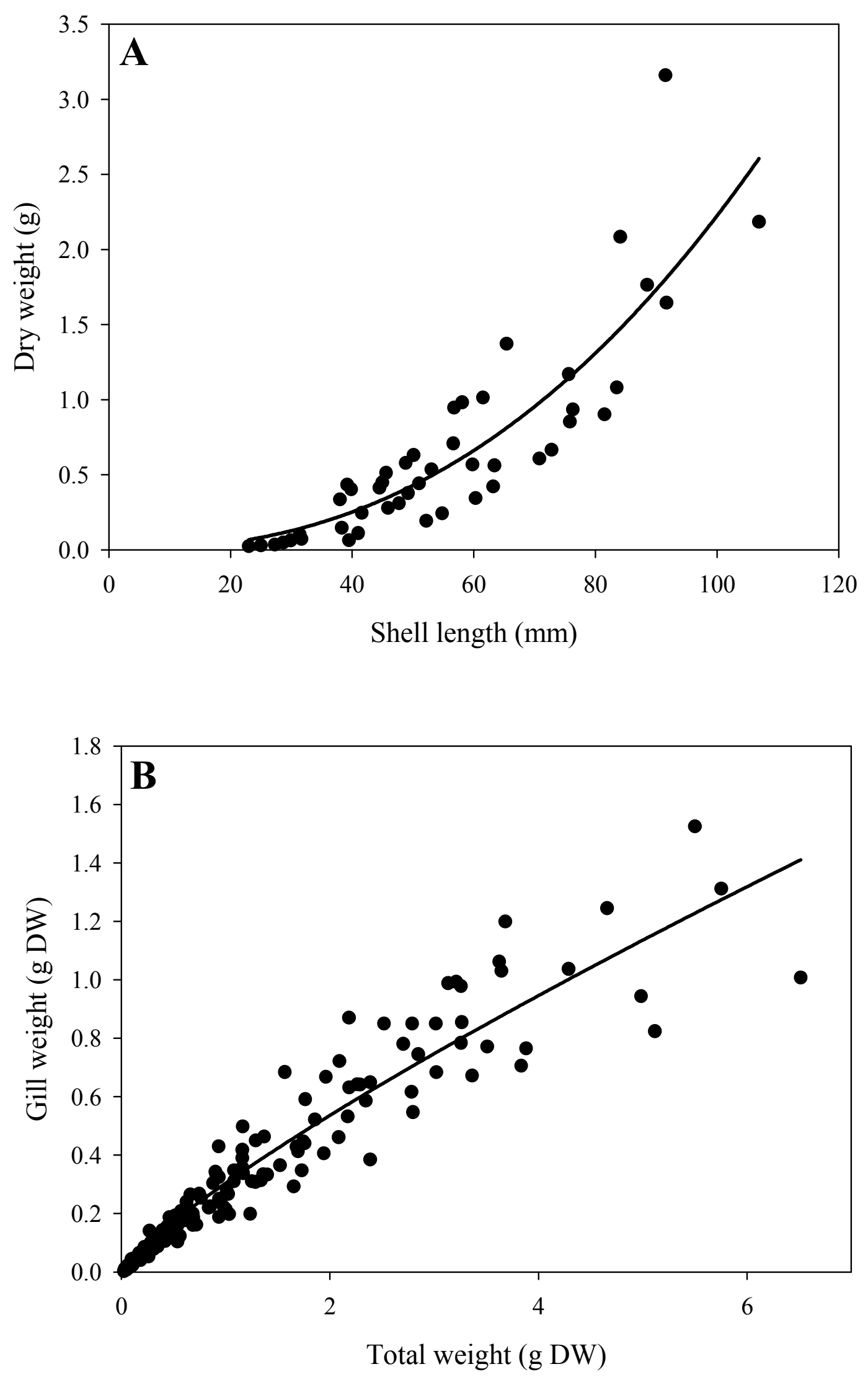

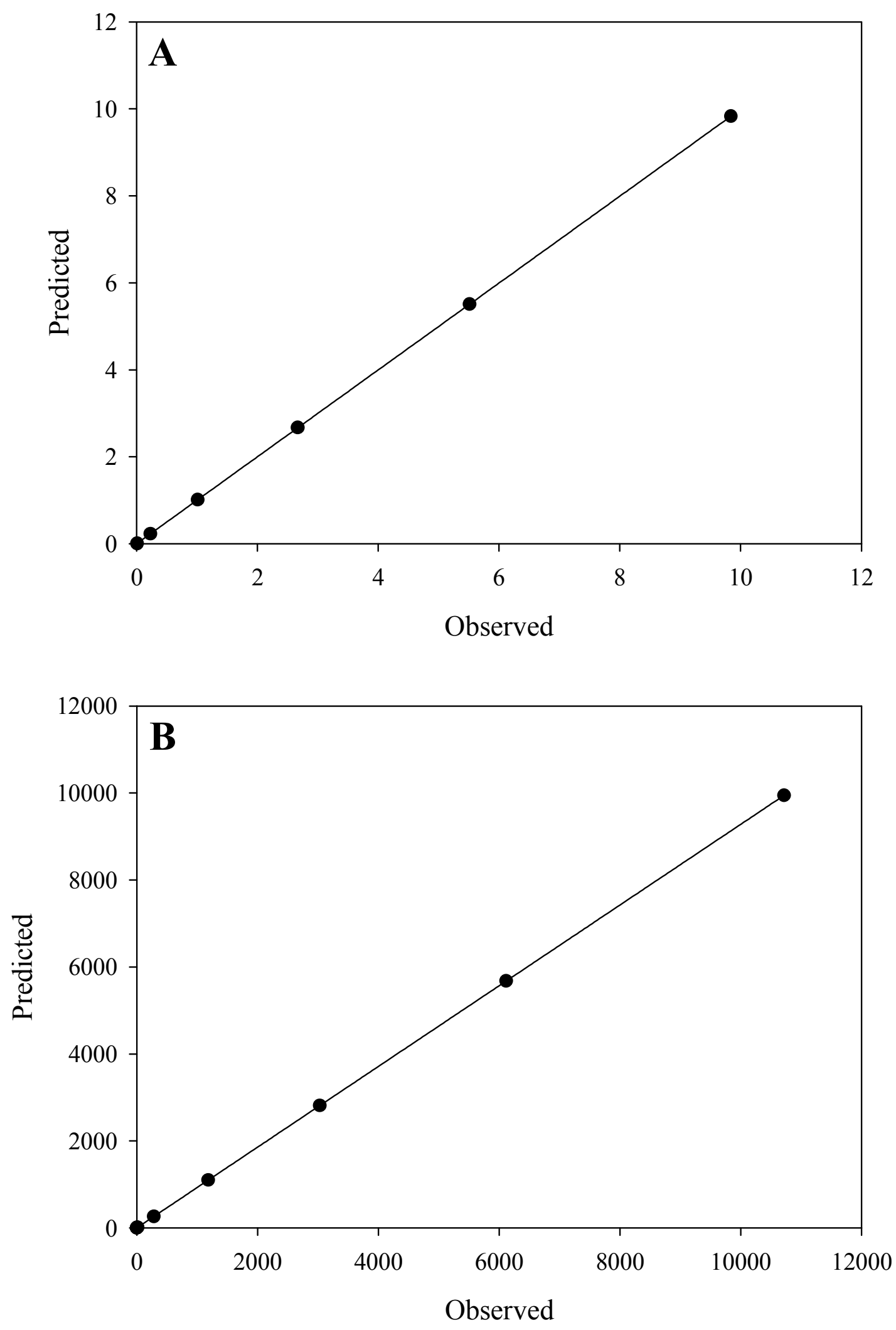

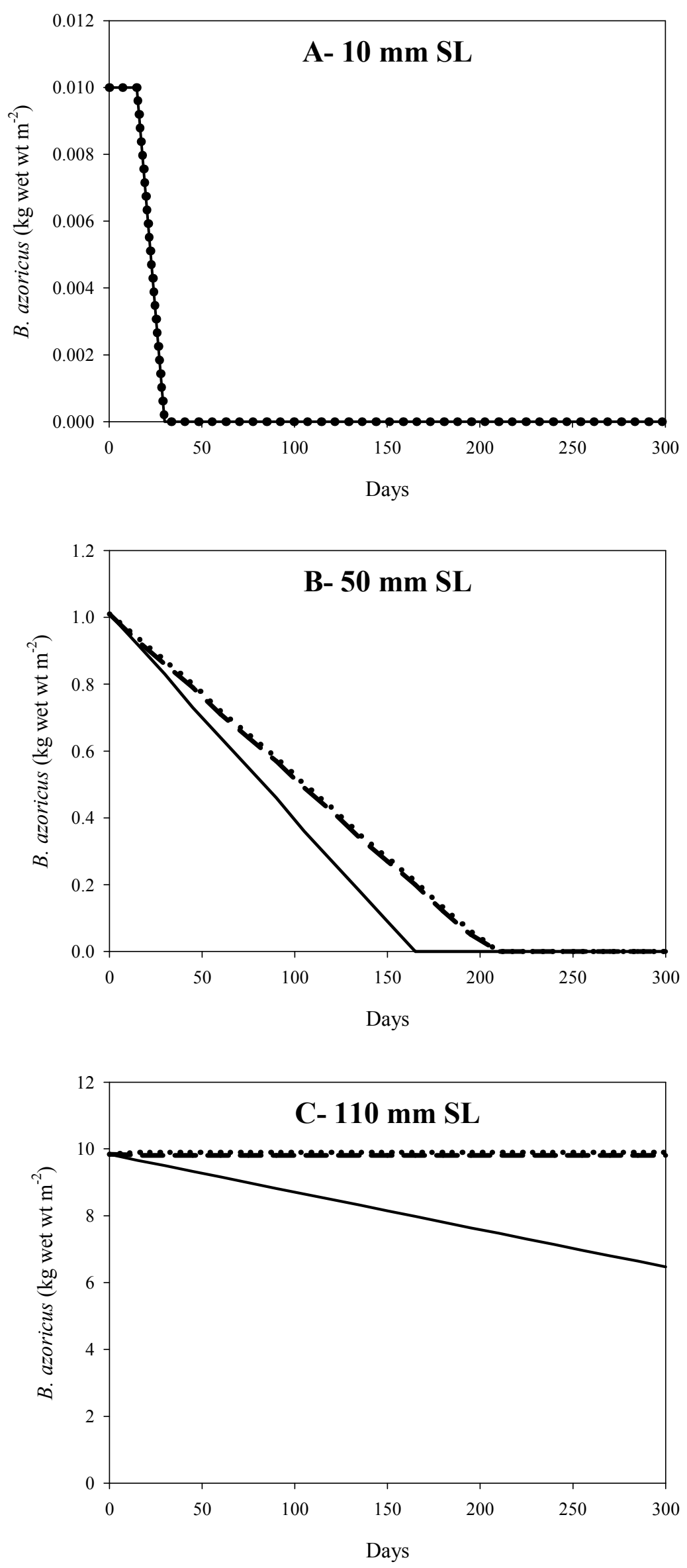

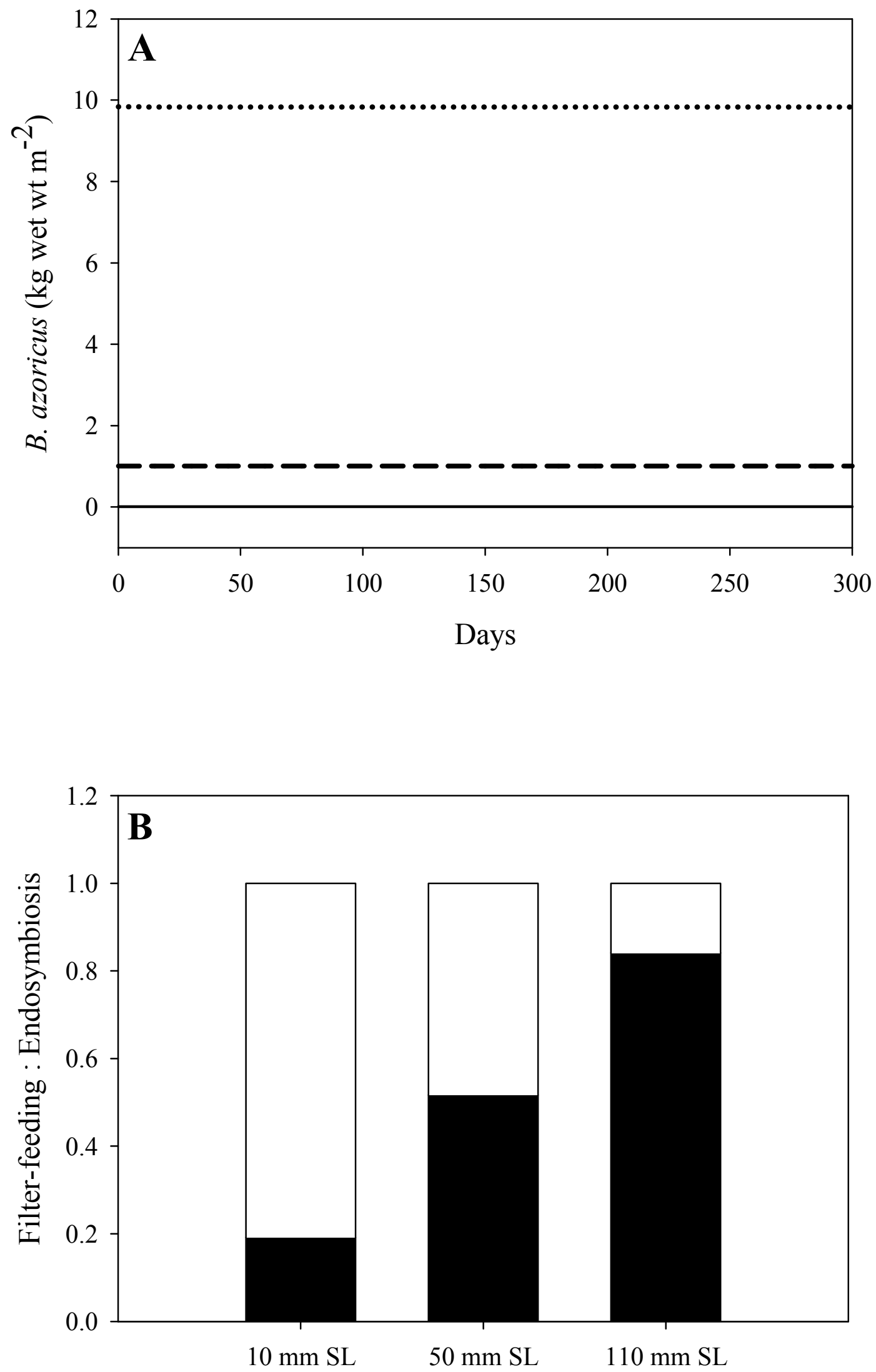

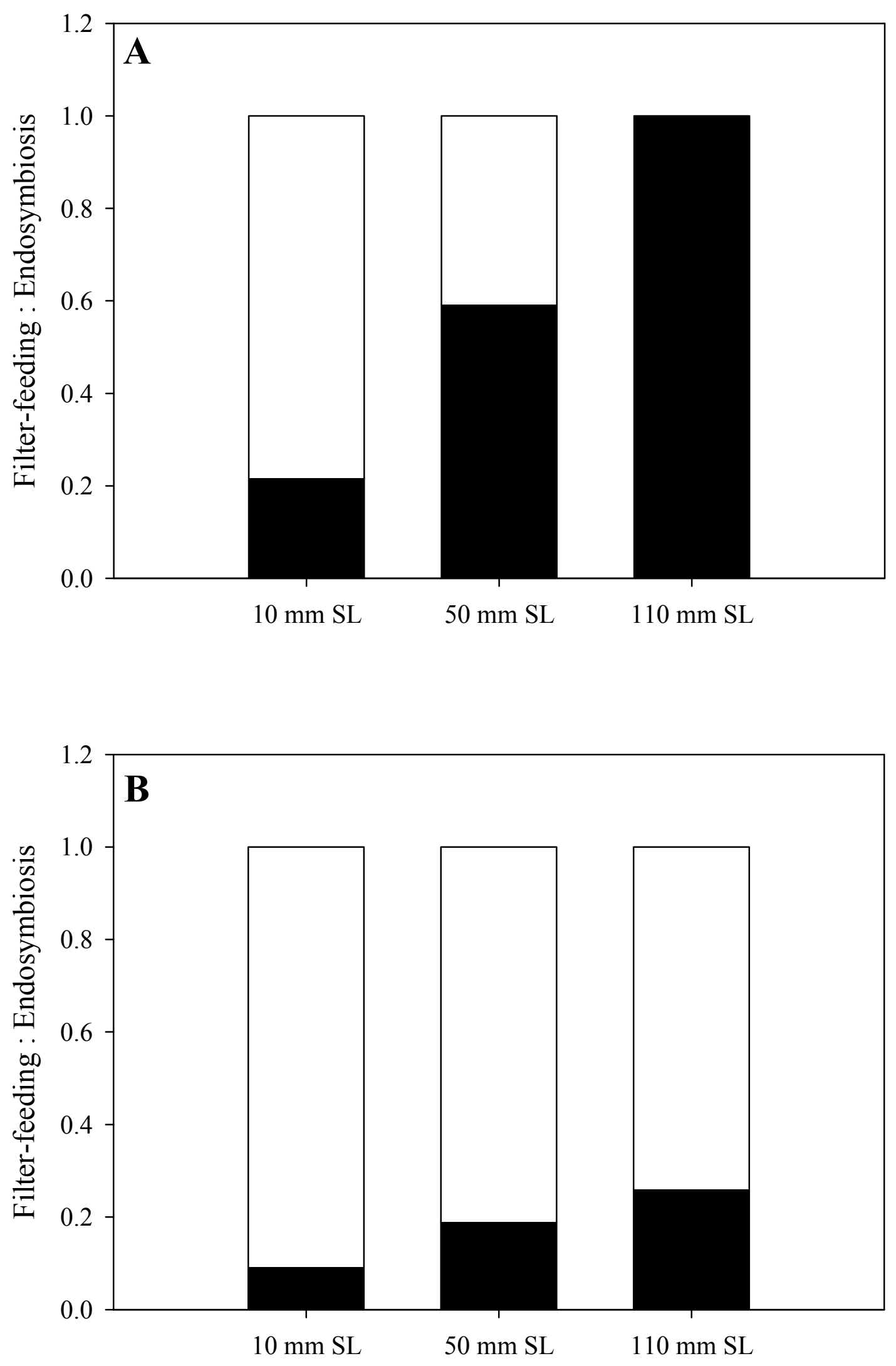


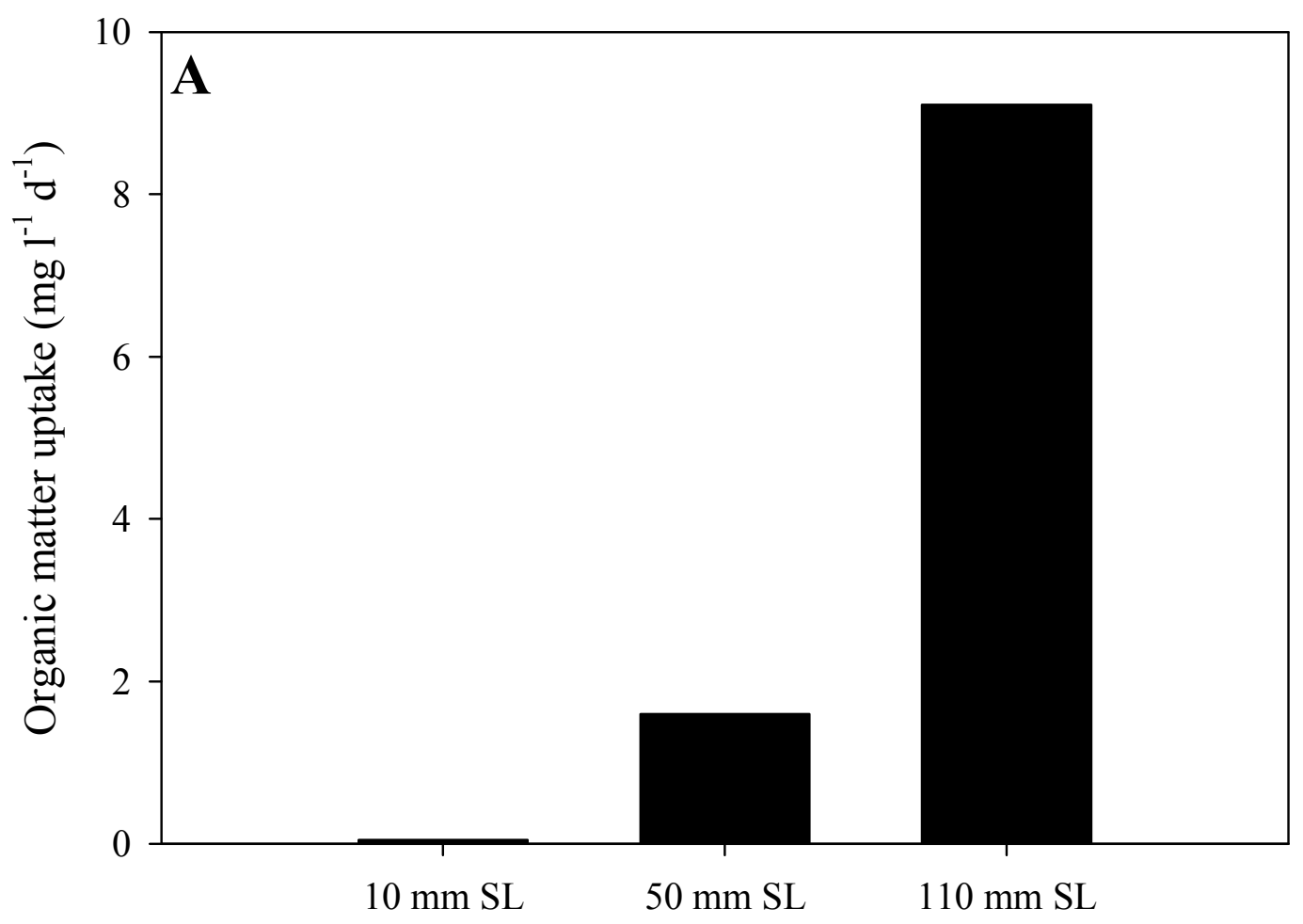



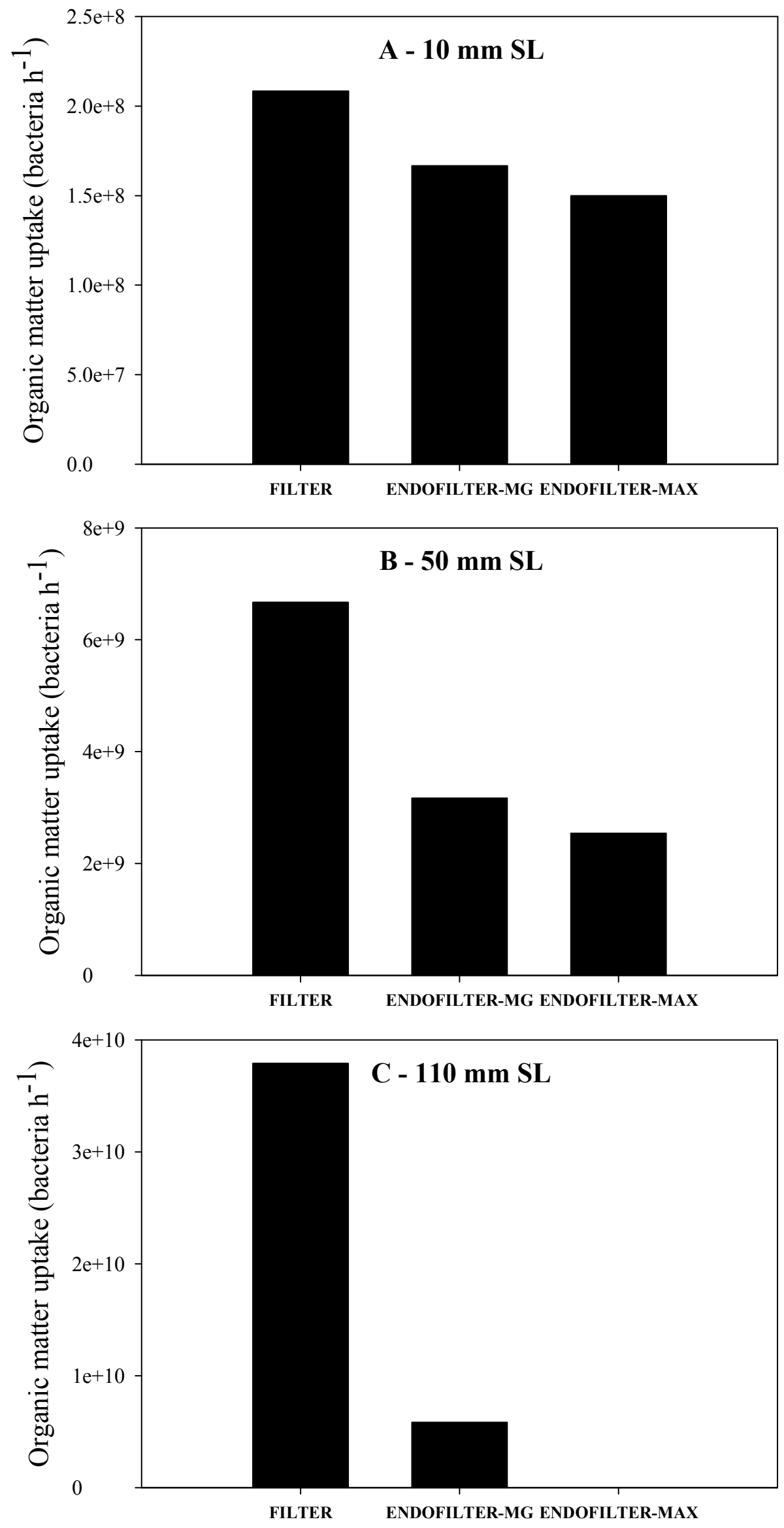

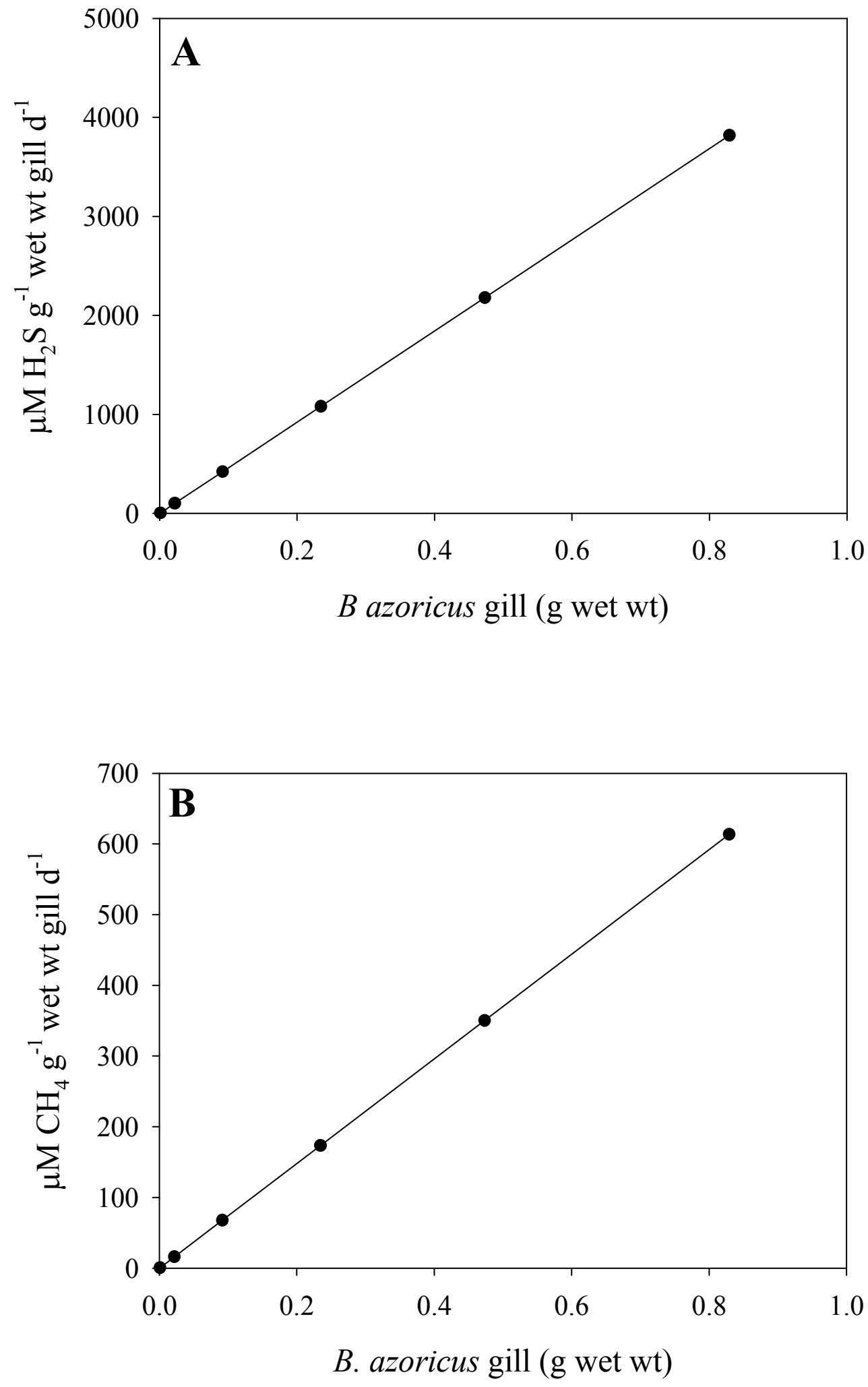